\title{
Delivery Mode and the Transition of Pioneering Gut-Microbiota Structure, Composition and Predicted Metabolic Function
}

\author{
Noel T. Mueller ${ }^{1,2, *,{ }^{\dagger}}$, Hakdong Shin ${ }^{3, \dagger}{ }^{\dagger}$, Aline Pizoni ${ }^{4}$, Isabel C. Werlang ${ }^{5}$, Ursula Matte ${ }^{5}$, \\ Marcelo Z. Goldani ${ }^{5}$, Helena A. S. Goldani ${ }^{4,5}$ and Maria G. Dominguez-Bello 1,6,* \\ 1 Department of Epidemiology, Johns Hopkins Bloomberg School of Public Health, Baltimore, MD 21205, USA \\ Welch Center for Prevention, Epidemiology and Clinical Research, Baltimore, MD 21205, USA \\ 3 Department of Food Science and Biotechnology, College of Life Science, Sejong University, \\ Seoul 05006, Korea; hakdong.shin@gmail.com \\ 4 Post Graduate Program Sciences in Gastroenterology and Hepatology, Federal University of Rio Grande \\ do Sul, Porto Alegre, RS 90040-060, Brazil; pizoni.aline@gmail.com (A.P.); hgoldani@hcpa.edu.br (H.A.S.G.) \\ 5 Post Graduate Program in Child and Adolescent Health, Federal University of Rio Grande do Sul, \\ Porto Alegre, RS 90040-060, Brazil; iwerlang@yahoo.com.br (I.C.W.); umatte@hcpa.edu.br (U.M.); \\ mgoldani@hcpa.edu.br (M.Z.G.) \\ 6 Division of Translational Medicine, New York University School of Medicine, New York, NY 10016, USA \\ * Correspondence: noeltmueller@jhu.edu (N.T.M.); Maria.Dominguez-Bello@nyumc.org (M.G.D.-B.); \\ Tel.: +1-410-614-7628 (N.T.M.) \\ + These authors contributed equally to this work.
}

Received: 18 October 2017; Accepted: 23 November 2017; Published: 4 December 2017

\begin{abstract}
Cesarean (C-section) delivery, recently shown to cause excess weight gain in mice, perturbs human neonatal gut microbiota development due to the lack of natural mother-to-newborn transfer of microbes. Neonates excrete first the in-utero intestinal content (referred to as meconium) hours after birth, followed by intestinal contents reflective of extra-uterine exposure (referred to as transition stool) 2 to 3 days after birth. It is not clear when the effect of C-section on the neonatal gut microbiota emerges. We examined bacterial DNA in carefully-collected meconium, and the subsequent transitional stool, from 59 neonates [13 born by scheduled C-section and 46 born by vaginal delivery] in a private hospital in Brazil. Bacterial DNA was extracted, and the V4 region of the $16 \mathrm{~S} r R N A$ gene was sequenced using the Illumina MiSeq (San Diego, CA, USA) platform. We found evidence of bacterial DNA in the majority of meconium samples in our study. The bacterial DNA structure (i.e., beta diversity) of meconium differed significantly from that of the transitional stool microbiota. There was a significant reduction in bacterial alpha diversity (e.g., number of observed bacterial species) and change in bacterial composition (e.g., reduced Proteobacteria) in the transition from meconium to stool. However, changes in predicted microbiota metabolic function from meconium to transitional stool were only observed in vaginally-delivered neonates. Within sample comparisons showed that delivery mode was significantly associated with bacterial structure, composition and predicted microbiota metabolic function in transitional-stool samples, but not in meconium samples. Specifically, compared to vaginally delivered neonates, the transitional stool of C-section delivered neonates had lower proportions of the genera Bacteroides, Parabacteroides and Clostridium. These differences led to C-section neonates having lower predicted abundance of microbial genes related to metabolism of amino and nucleotide sugars, and higher abundance of genes related to fatty-acid metabolism, amino-acid degradation and xenobiotics biodegradation. In summary, microbiota diversity was reduced in the transition from meconium to stool, and the association of delivery mode with microbiota structure, composition and predicted metabolic function was not observed until the passing of the transitional stool after meconium.
\end{abstract}

Keywords: cesarean section; microbiome; microbiota; microbial community; obesity 


\section{Introduction}

C-section delivery is a common surgical procedure intended to increase the chances of successful delivery and to protect the health of the mother. Yet this highly overused intervention [1-4] has been associated with higher offspring risk of immune and metabolic disorders [5-8] and shown to cause excess weight gain in a murine model [9]. It is hypothesized that these associations are due to C-section-delivered neonates not receiving the full inoculum of maternal microbes at birth [7].

Neonates delivered vaginally are exposed to maternal vaginal microbiota in labor, and additionally to maternal intestinal microbiota at birth [10-13]. C-section and the prophylactic antibiotics administered during this surgery [14] may cause newborns to miss this natural microbial inoculum [14-16]. C-section-delivered neonates are first exposed to microbes from the delivery room [17] and maternal skin (e.g., Staphylococcus and Corynebacterium) [15]. Recent longitudinal studies suggest the postnatal impact of delivery mode on the infant microbiome may extend for up to two years $[16,18]$. Yet, since the intestine of the newborn at birth is filled with in-utero contents, which are passed postnatally as meconium, it is unclear when the differences in the gut microbiota of $\mathrm{C}$-section versus vaginally-delivered neonates begin to emerge.

Findings of bacterial DNA in the placenta, amniotic fluid, and newborn meconium have given rise to the hypothesis that the human fetus may be exposed to microbiota in utero through ingestion of amniotic fluid [16,19-21]. Yet no evidence exists for fetal exposure to live bacteria in healthy pregnancies. If microbiota colonize the fetal intestinal tract before labor and birth, this microbial colony should be reflected in the meconium, but not be impacted, or be impacted to a lesser extent, by delivery mode. Thus, we hypothesized that a higher delivery-mode signal should be found in the microbiota of the feces passed after meconium (i.e., transitional stool). To test this hypothesis, we compared the composition, structure and predicted metabolic function of microbiota in meconium and the subsequent transitional stool from neonates born by scheduled elective C-section vs. vaginal delivery.

\section{Materials and Methods}

\subsection{Design and Subjects}

Trained staff invited women to participate in the study if they were scheduled for a vaginal delivery or an elective C-section delivery between 38 and 42 weeks of gestation (confirmed by an ultrasound taken before the 20th week of pregnancy) in the participating private hospital in Porto Alegre, Brazil. Women were not eligible for the study if they were administered oral antibiotics in the third trimester of pregnancy; if they had diabetes, hypertensive disorders, autoimmune disorders, or HIV / AIDS during pregnancy; if they had smoked during pregnancy; or if they were on a restrictive diet during pregnancy. For vaginal births, we further only included women whose water broke less than $12 \mathrm{~h}$ before delivery. All vaginal deliveries were by spontaneous vaginal birth and no instruments were used. Women also had to consent to allowing study staff collect meconium or stool from their neonate, and to completing a postnatal questionnaire. The Research and Ethics Committee of the Hospital de Clinicas (protocol No. 11/0388) and the Hospital Mae de Deus (protocol No. 524/11) in Porto Alegre, Brazil, approved the study protocols and consent.

From medical records, we ascertained information on mode of delivery, gravidity, parity, history of urinary tract infection during pregnancy, antibiotic use during pregnancy, birth weight, labor length, head circumference, placenta weight, sex and race. Other clinical information was derived from a questionnaire administered after birth before discharge.

\subsection{Sample Collection and $16 S$ Ribosomal RNA Sequencing}

Of the 89 mother-child pairs who consented and enrolled in the original study, we were able to collect 78 meconium samples (collected within $48 \mathrm{~h}$ of birth; all but 2 were collected $<24 \mathrm{~h}$ ). From the 78 meconium samples, 59 (75.6\%) had detectable bacterial DNA. Transitional stool samples (collected 2-3 days after birth) with detectable bacterial DNA for analysis were available for 50 of 59 of these 
neonates. All specimens were collected from diapers with sterile spatulas, transferred to sterile tubes, which were kept at $4{ }^{\circ} \mathrm{C}$ for $<6 \mathrm{~h}$, and then frozen at $-80^{\circ} \mathrm{C}$ until DNA extraction.

Total DNA was extracted using QIAamp ${ }^{\circledR}$ DNA Stool mini kit (QIAGEN) according to the manufacturer's instructions. After DNA extraction ( $200 \mu \mathrm{L}$ of final volume), we concentrated DNA samples to $20 \mu \mathrm{L}$ using $3 \mathrm{M} \mathrm{Na}$ Acetate precipitation and kept it stored at $-20{ }^{\circ} \mathrm{C}$. We determined the DNA concentration of prepared samples using the Quant-iT PicoGreen dsDNA reagent and kit (Invitrogen, Grand Island, NY, USA) based on the manufacturer's instructions. We amplified the V4 region of the $16 \mathrm{~S}$ ribosomal RNA (rRNA) gene by polymerase chain reaction (PCR) using the Illumina-adapted universal primers 515F/806R [22]. PCR was done in triplicate using the Bio-Rad CFX 96 thermal cycler (Bio-Rad, Hercules, CA, USA). We then pooled the amplicons in equimolar ratios, purified them using QIA quick PCR purification kit (Qiagen Inc., Chatsworth, CA, USA), and sequenced them on the Illlumina MiSeq platform (Genome Technology Center of NYU Medical Center, NY, USA) using a paired-end technique. Reagents for DNA extraction and for PCR amplification were sequenced as negative controls.

\section{3. $16 \mathrm{~S}$ rRNA Gene Sequence Analysis}

We analyzed 16S rRNA gene sequence data using the Quantitative Insights Into Microbial Ecology (QIIME) software package (v1.8) [23]. Using qualified sequences (Phred $\geq$ Q20), we identified and quantified Operational Taxonomic Units (OTUs) using an open-reference method that maps sequences with $97 \%$ identity to known sequences in the Greengenes database (v13_8) [24] using UCLUST [25] and PyNAST [26] alignment algorithms. We used ChimeraSlayer to identify chimeric sequences. Negative-control derived OTUs were discarded from the OTU table using a filtration script (filter_otus_from_otu_table.py) in QIIME.

We rarefied to 1634 reads per sample to calculate microbial diversity. We calculated alpha diversity using the phylogenetic distance and the detected number of species metrics. Principle coordinate analysis ( $\mathrm{PCoA}$ ) with weighted Unifrac distance metric were used to evaluate beta diversity (i.e., the variation in microbial community composition) between $\mathrm{C}$-section and vaginally-delivered neonatal fecal samples [27]. We performed permutational multivariate analysis of variance (PERMANOVA) to determine the significance of differences in beta diversity by delivery mode. PERMANOVA, which partitions inter-group and intra-group distances, is a permutation-based extension of multivariate analysis of variance to a matrix of pairwise distances [28]. We also used non-parametric $t$ tests with 10,000 Monte Carlo permutations for significant test of microbial diversity.

We used linear discriminant analysis (LDA) effect size (LEfSe) [29] to identify biologically and statistically significant differences OTU relative abundance. We then used Phylogenetics Investigation of Communities by Reconstruction of Unobserved States (PICRUSt) to predict the metabolic function of the metagenomes from the 16S rRNA gene dataset [30], with Kyoto Encyclopedia of Genes and Genomes (KEGG) Orthologs classification [31]. An LDA score of $>3$ (among OTUs with at least $>1 \%$ relative abundance in any group) was used to determine significant differences in abundance of OTUs and metabolic pathways.

\section{Results}

\subsection{Neonates and Samples}

Of the 78 neonates that provided meconium samples, $59(75.6 \%)$ had bacterial DNA present in their meconium. There were no significant differences in the clinical characteristics of mothers or neonates who had meconium with vs. without detectable bacterial DNA. Of the 59 neonates with meconium bacterial DNA, 50 also provided a subsequent transitional stool sample with bacterial DNA. We analyzed the meconium and transitional stool from these neonates for the current study. Demographic, clinical, and anthropometric characteristics of the 59 neonates (13 from 
vaginally-delivered neonates; 46 from C-section neonates) who had meconium with detectable bacterial DNA (and their mothers) are presented in Table 1 according to delivery mode.

Table 1. Characteristics * of Brazilian mothers and their newborns who had meconium microbiota.

\begin{tabular}{|c|c|c|}
\hline & $\begin{array}{c}\text { Vaginal Delivery } \\
\quad(n=13)\end{array}$ & $\begin{array}{c}\text { C-Section Delivery } \\
(n=46)\end{array}$ \\
\hline \multicolumn{3}{|l|}{ Maternal characteristics } \\
\hline Mothers age, $\mathrm{y}$ & $28.5(5.9)$ & $30.5(4.7)$ \\
\hline \multicolumn{3}{|l|}{ Mothers race } \\
\hline White, $n(\%)$ & $12(92)$ & $42(91)$ \\
\hline Non-white, $n(\%)$ & $1(8)$ & $4(9)$ \\
\hline \multicolumn{3}{|l|}{ Urinary tract infection } \\
\hline Yes, $n(\%)$ & $4(31)$ & $6(13)$ \\
\hline No, $n(\%)$ & $9(69)$ & $40(87)$ \\
\hline \multicolumn{3}{|l|}{ Medications in pregnancy } \\
\hline Yes, $n(\%)$ & $4(31)$ & $19(41)$ \\
\hline No, $n(\%)$ & $9(69)$ & $27(59)$ \\
\hline \multicolumn{3}{|l|}{ Antibiotics in pregnancy } \\
\hline None, $n(\%)$ & $9(69)$ & $36(78)$ \\
\hline 1st Trimester, $n(\%)$ & $1(8)$ & $5(11)$ \\
\hline 2nd Trimester, $n(\%)$ & $3(23)$ & $5(11)$ \\
\hline \multicolumn{3}{|l|}{ Ever smoke tobacco } \\
\hline Yes $(\%)$ & $0(0)$ & $12(26)$ \\
\hline No $(\%)$ & $13(100)$ & $34(74)$ \\
\hline Pre-pregnancy BMI, kg/m² & $22.4(3.2)$ & $25.3(5.0)$ \\
\hline Pregnancy weight gain, kg & $13.0(3.0)$ & $13.7(5.4)$ \\
\hline \multicolumn{3}{|l|}{ Newborn characteristics } \\
\hline \multicolumn{3}{|l|}{ Sex } \\
\hline Boy, $n(\%)$ & $3(23)$ & $30(65)$ \\
\hline Girl, $n(\%)$ & $10(77)$ & $16(35)$ \\
\hline Birth weight, g & $3127.6(334.5)$ & $3234.3(427.4)$ \\
\hline Birth length, cm & $48.7(2.2)$ & $48.9(1.6)$ \\
\hline Head circumference, $\mathrm{cm}^{+}$ & $35.9(4.4)$ & $35.7(2.8)$ \\
\hline Placenta weight, g $\S$ & $674.8(91.3)$ & $624.2(131.7)$ \\
\hline \multicolumn{3}{|l|}{ Breastfed 1st $24 \mathrm{~h}$} \\
\hline Yes, $n(\%)$ & $13(100)$ & $40(87)$ \\
\hline No, $n(\%)$ & $0(0)$ & $6(13)$ \\
\hline
\end{tabular}

* values expressed as mean (standard deviation) if not otherwise indicated as $n(\%) ;{ }^{\dagger}$ based on 10 vaginally-delivered and $43 \mathrm{C}$-section delivered neonates with data; $\$$ based on 10 vaginally-delivered and $39 \mathrm{C}$-section delivered neonates with data.

\subsection{Microbial Community Diversity, Abundance and Predicted Function}

We obtained 604,570 sequences (paired-end, Phred $\geq$ Q20) from the 59 meconium samples, and 472,165 sequences from the 50 transitional stools. There was an average of 9878 reads per sample, binned into 5939 Operating Taxonomic Units (OTUs; Table S1). Alpha diversity was greater for 
meconium than for transitional stool samples, regardless of delivery mode (Figure 1; Phylogenetic diversity whole tree, $p<0.005$; Observed species, $p<0.05$ ).
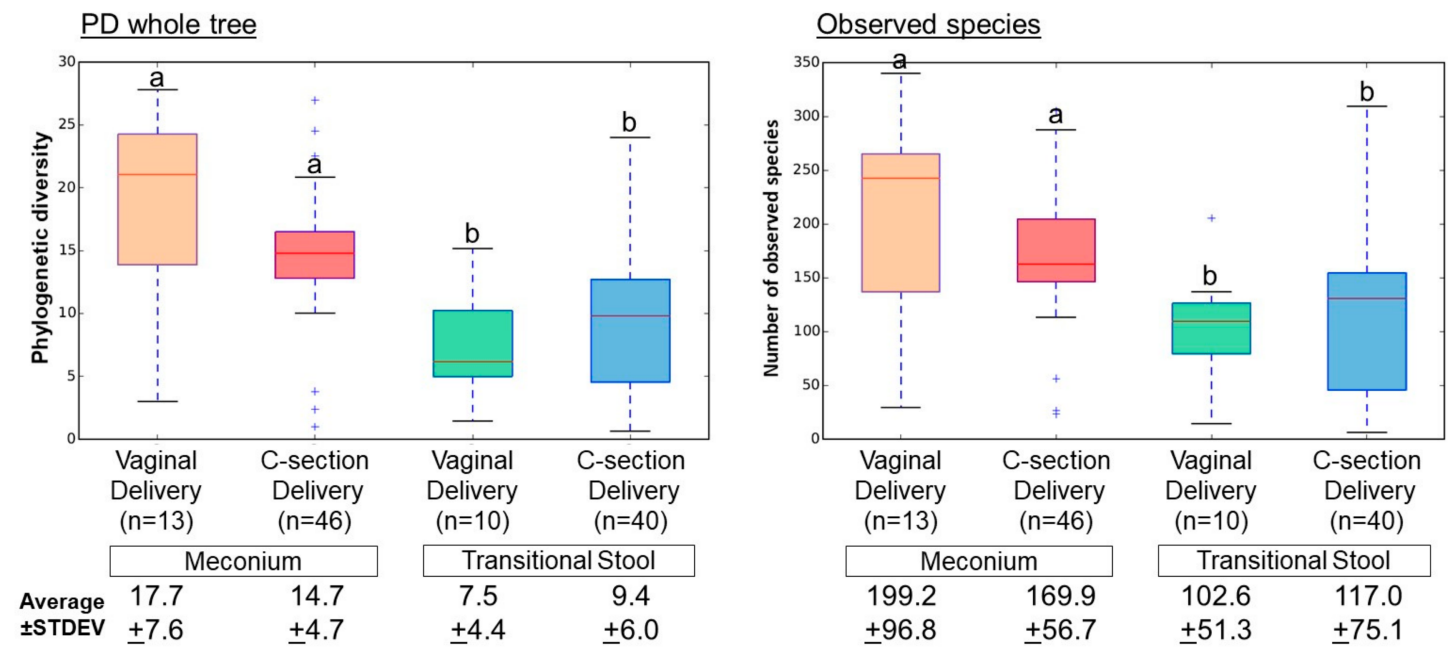

Figure 1. Bacterial alpha diversity in the meconium and transitional stool by delivery mode. Samples were rarefied to 1634 reads per sample. The nonparametric $p$ values were calculated using 100,000 Monte Carlo permutation. Different letters indicate significant differences (e.g., ' $a$ ' is significantly different from ' $b$ ', but not significantly different from ' $a$ '); Statistical significance for phylogenetic diversity (PD) whole tree, $p<0.005$; Observed species, $p<0.05$. +, outlier samples.

Microbial community structure (beta diversity) did not differ significantly by delivery mode in the meconium (Figure 2A; Weighted UniFrac; PERMANOVA, $p=0.1047$ ). It did, however, vary in the transitional stools (Figure 2B; Weighted UniFrac; PERMANOVA, $p<0.0001$ ). There were also inter-individual differences in microbiota (Figure S1), which varied by group. Transitional stool samples had higher variability then meconium, particularly transitional stools from babies born vaginally (Figure 2D and Figures S1 and S2A; Weighted UniFrac; non-parametric $t$-test, $p<0.001$ ).

(A)

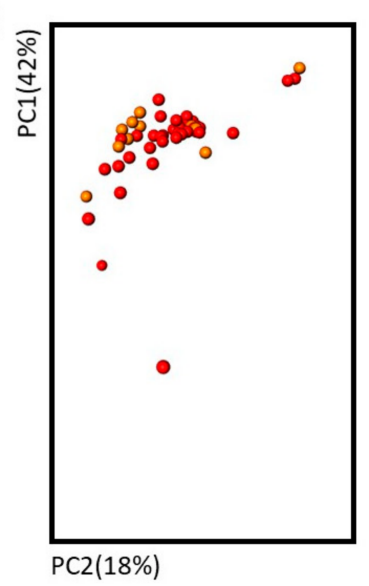

(B)

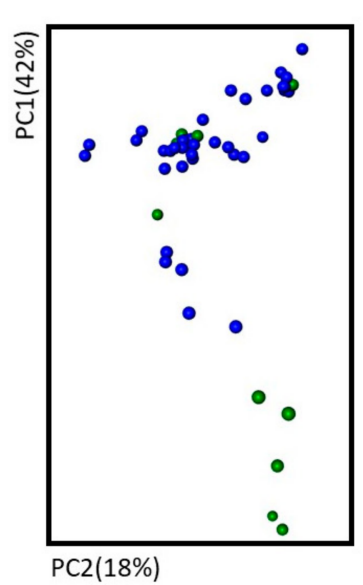

(C)

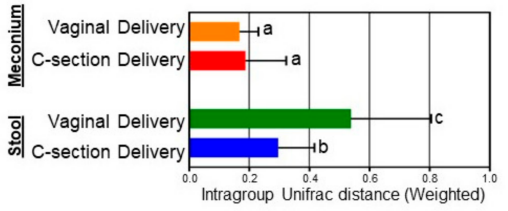

Meconium

Vaginal Delivery $(n=13)$ permanova

C-section Delivery $(\mathrm{n}=46)]_{p=0.1047}$

Transitional Stool

Vaginal Delivery $(n=10) \quad$ PERMANova

C-section Delivery $(\mathrm{n}=40)]_{p<0.0001}$

Figure 2. Bacterial diversity in the meconium and transitional stool by delivery mode. (A-C) Principal Coordinate Analysis (PCoA) plot of bacterial communities in meconium (A) and transitional stool (B) by delivery mode. Weighted UniFrac distances were used to evaluate diversity between samples. PERMANOVA was used to test dissimilarity. (C) Box plot of intra-group distances. The non-parametric $p$ values were calculated using 100,000 Monte Carlo permutation. Different letters ( $a, b$ and $c)$ indicate significant differences; $p<0.001$. 
Both variability and the bacterial community structure in the neonatal gut changed during the transition from meconium to the transitional stool (Figure 2A,B and Figures S1 and S2A). We used linear discriminant analysis (LDA) effect size (LEfSe), retaining bacterial OTUs with $>1 \%$ abundance, and found no significant delivery-mode differences in meconium microbiota. However, in the transitional-stool microbiota, LEfSe detected a significantly higher relative abundance of the genera Bacteroidetes, Parabacteroides and Clostridium in vaginally-delivered neonates as compared to C-section delivered neonates (LDA > 3.0; Figure 3).

(A)

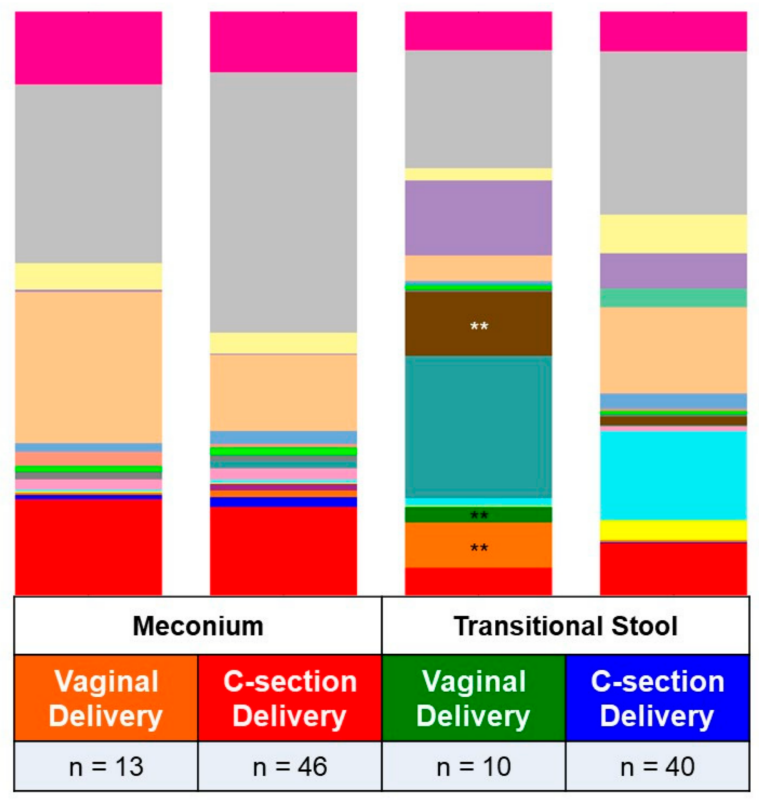

(B)

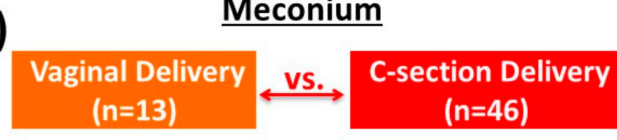

No significant differences

\begin{tabular}{|l|l|}
\hline & p_Proteobacteria.f_Xanthomonadaceae.g__ \\
\hline & p_Proteobacteria.g_Pseudomonas \\
\hline & p_Proteobacteria.g_Acinetobacter \\
\hline & p_Proteobacteria.g_Trabulsiella \\
\hline p_Proteobacteria.g_Erwinia \\
\hline p_Proteobacteria.f_Enterobacteriaceae.g_ \\
\hline p_Proteobacteria.f_Enterobacteriaceae.Other \\
\hline p_Proteobacteria.g_Hydrogenophilus \\
\hline p_Proteobacteria.g_Cupriavidus \\
\hline p_Proteobacteria.g_Sphingomonas \\
\hline p_Firmicutes.g_Clostridium ${ }^{* *}$ \\
\hline p_Firmicutes.f_Clostridiaceae.g_ \\
\hline p_Firmicutes.g_Streptococcus \\
\hline p_Firmicutes.g_Enterococcus \\
\hline p_Firmicutes.g_Staphylococcus \\
\hline p_Cyanobacteria.c_Chloroplast.o_.f_g_g \\
\hline p_Bacteroidetes.g_Parabacteroides ** \\
\hline p_Bacteroidetes.g_Bacteroides $* *$ \\
\hline p_Actinobacteria.g_Corynebacterium \\
\hline Minor_OTUs \\
\hline
\end{tabular}

\section{Transitional Stool}

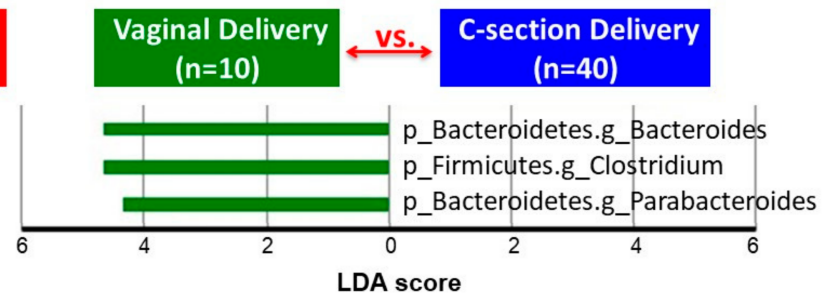

Figure 3. Bacterial taxa comparisons in meconium and transitional stool by delivery mode. (A) Each taxonomy ( $>1 \%$ of average relative abundance in any groups) is indicated by a different color at the genus level. ** Indicates overrepresented taxa (using LDA > 3.0) in comparisons of delivery mode within sample type; (B) Histogram of overrepresented taxa (using LDA > 3.0) in each group.

Microbial metagenomic functioning predictions using PICRUSt provided further insight into the predicted metagenome functional profiles, again showing delivery-mode differences in the transitional stools, but not in the meconium samples (Table 2). Of note, transitional stool from the vaginally-delivered neonates had a higher proportion of bacterial genes related to amino sugar and nucleotide sugar metabolism, whereas stool microbiota from C-section neonates had higher abundance of genes related to tryptophan, valine, leucine and isoleucine degradation, fatty acid metabolism, and xenobiotics biodegradation and metabolism (LDA > 3.0; Table 2). Interestingly, microbiota differences in the transition of C-section neonatal fecal samples (Figure S2A) did not translate into differences in predicted microbial-metagenomic functional profiles, as they did in vaginally-delivered neonatal fecal samples (Table 2; Figure S2B). These results indicate relatively 
slower maturation of microbiome metabolic functions in the gut of C-section vs. vaginally-delivered neonates during the first days of life.

Table 2. Predictive KEGG functional profiling of microbiota from transitional stools-but not from meconium-differ by delivery mode. *

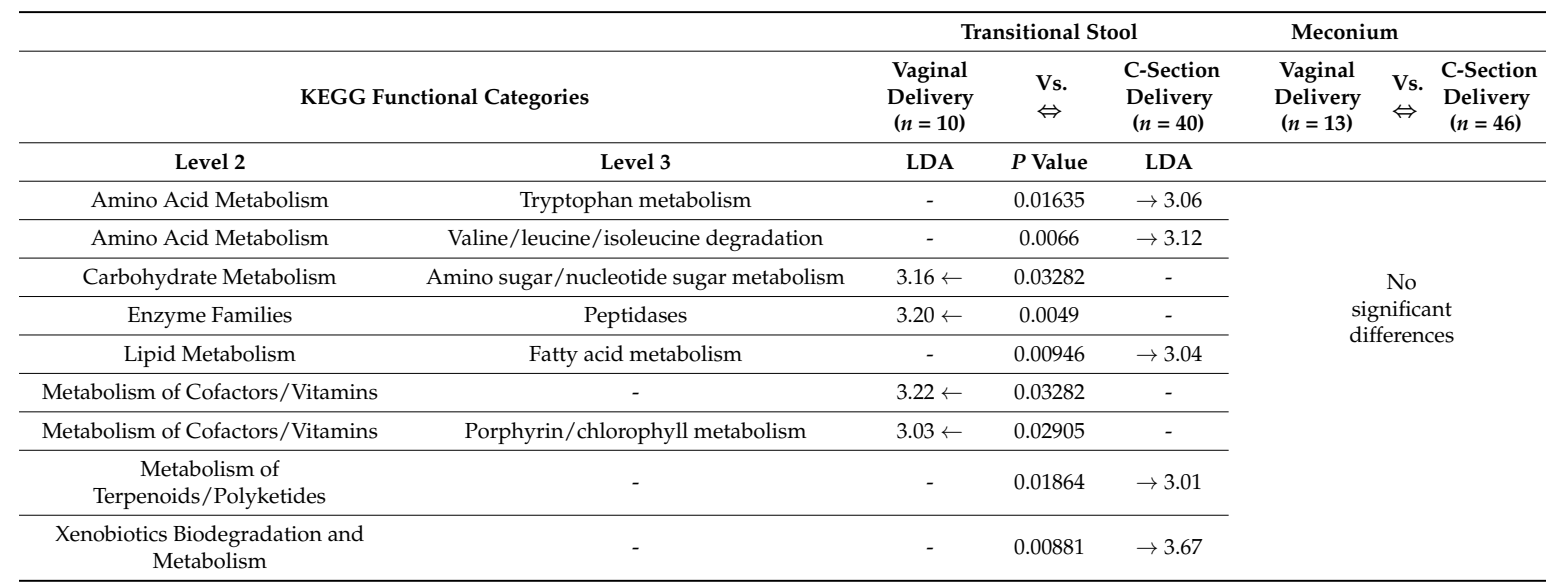

* Significantly overrepresented KEGG functional categories in predicted metagenomes by delivery mode were detected using Linear Discriminant Analysis (LDA) Effect Size $>3.0$-fold with direction indicated by arrow $(\leftarrow$ or $\rightarrow$ ).

\section{Discussion}

In our cohort from Southern Brazil, we found that the transition from meconium to stool involves altered bacterial structure, composition and decreasing alpha diversity, and that delivery mode-associated differences in bacterial diversity, OTU abundances and predicted metagenomic functions arise not in the meconium, but in the transitional stool passed after meconium.

Our findings on the transition in microbiome composition and structure from meconium to transitional stool are consistent with previous work reporting loss of alpha diversity postnatally in mice [32] and human neonates [33]. Selective environmental pressures, such as human milk oligosaccharides found in breast milk, may drive the reduction in microbial diversity from meconium to transitional stool. Our finding (Figure S2A) that initial blooms of Streptococous and several Proteobacteria phylotypes in meconium were replaced by bacteria in the Clostridiaceae family (e.g., Lactobacillus spp.) in transitional stool of vaginally born neonates, is also consistent with findings in mice [32]. Lactobacilli are facultative anaerobes that ferment milk lactose and casein and produce lactate [34-36]. Lactic acid lowers the $\mathrm{pH}$ of the intestinal contents, inhibiting growth of obligate anaerobes [35,37] commonly found in meconium. The role of this initial reduction in diversity on education of host immune development and metabolic health remains to be elucidated.

Previous investigations on the impact of delivery mode on meconium bacterial composition have been mixed, with some studies having found differences [15,16,38], and others [39] not. Rocio et al. reported differences in bacterial counts in the meconium by mode of delivery among 108 neonates (80 vaginally-delivered and $28 \mathrm{C}$-section) [16]. They also reported differences in microbiota composition over the first 3 months, analyzing 33 different bacterial taxa by quantitative reverse transcription PCR in meconium, 2nd-day stool (transitional stool), and 7-, 30-, and 90-day stools; it is unclear from their study when compositional differences emerged [16]. Our statistical power to detect large differences may have been limited by the relatively small number of vaginally-delivered neonates in our sample. However, we were able to discern microbiota differences in transitional stools from 10 vaginally-delivered and $40 \mathrm{C}$-section neonates, and these findings are consistent with a larger sample of transitional stools [40]. Discrepancies between our study and other studies on this topic might reflect collection, storage processing or analytic platforms [41]. Differences may also be due to inter-hospital differences in delivery-mode practices, including intrapartum antibiotic administration. While we excluded 3rd-trimester antibiotics, the standard protocol for operative C-section in our 
hospital in Porto Alegre is intravenous intrapartum administration of cefazolin (half-life $120 \mathrm{~min}$ ), 30 to $60 \mathrm{~min}$ before surgery [42,43]. A recent study found intrapartum antibiotics were associated with an impacted infant microbiome [14]. Thus, it is possible the impact of C-section observed in our study includes the effect of intrapartum antibiotics.

Our amplicon-sequencing results compliment previous studies [10-12] that demonstrated mother-to-newborn transmission at the strain level. Makino et al. have shown that stains found in the mother before delivery, were also found in the meconium [10]. They have also reported the differences in transmission Bifidobacterium strains by delivery mode in 12 vaginally-delivered neonates and 5 C-section neonates, but only at 3 days after birth [11]. In the light of studies showing evidence of bacterial DNA in amniotic fluid [44,45], chorioamnion tissue [46], cord blood [47], fetal membranes [48], and the placenta [19], some investigators have taken evidence of bacterial DNA in meconium to suggest potential translocation of microbiota from mother to fetus before birth. This has been called the 'in-utero colonization hypothesis' [41]. However, no study, to our knowledge, has shown evidence of live bacteria in utero in healthy pregnancies. Regardless of viability, intrauterine maternal bacterial DNA might be important in intestinal transcriptional profiles programming of the offspring conferring to them protection against pathogen colonization [49].

The detection of bacterial DNA in the meconium samples in our study does not clearly support nor refute the in-utero colonization hypothesis, as meconium may reflect not only prenatal but also peri- and postnatal exposures [41]. About 75\% of meconium samples in our study contained detectable microbial DNA; other studies have found similar [16] or lower prevalence of microbes in meconium [50-52]. Presence of microbes in meconium has been shown to increase with time [51], which one might take to support the hypothesis that intestinal colonization starts postnatally [41]. Yet, if the bacterial DNA present in the meconium of our study was acquired postnatally, one would expect the composition and structure to be altered by delivery mode, as was observed in the microbiota of the subsequent transitional stools in our study.

\section{Conclusions}

In summary, we found evidence of bacterial DNA in most meconium samples and we observed that bacterial diversity in the neonatal intestinal tract decreases in the first days of life, from the passing of meconium to transitional stool. Moreover, the initial transition in neonatal intestinal bacterial structure, composition and predicted metagenome function appears to be impacted by delivery mode. Our findings also add to the literature that vaginal birth-acquired microbes are important in the normal development of the early neonatal gut microbiota development and also their metabolic function, since C-section delivered neonates fail to show transitional changes in predicted bacterial metagenomic functions. Future research should determine whether the differential transition of these pioneering microbial communities and their metagenomic functions are on the pathway to the metabolic and immune-mediated diseases that have been associated with $\mathrm{C}$-section delivery.

Supplementary Materials: The following are available online at: www.mdpi.com/2073-4425/8/12/364/s1. Correspondence and requests for materials should be addressed to N.T.M. and M.G.D.-B.

Acknowledgments: This study was conducted using academic funds from the Ministry of Education (Capes), and FIPE-HCPA, UFRGS. H.S. was supported by Basic Science Research Program through the National Research Foundation of Korea (NRF) funded by the Ministry of Education (NRF-2017R1D1A1B03029911).

Author Contributions: N.T.M., M.G.D.-B. and H.A.S.G. designed this study. A.P., I.C.W., U.M. and M.Z.G. implemented the sample collection. N.T.M., H.S. and M.G.D.-B. performed analyses and interpreted results. N.T.M., H.S., U.M., H.A.S.G., M.Z.G. and M.G.D.-B. wrote the paper. All authors reviewed the manuscript.

Conflicts of Interest: The authors declare no conflict of interest.

\section{References}

1. Lavender, T.; Hofmeyr, G.J.; Neilson, J.P.; Kingdon, C.; Gyte, G.M. Caesarean section for non-medical reasons at term. Cochrane Database Syst. Rev. 2012, 14. [CrossRef] 
2. American College of Obstetricians and Gynecologists (College); Society for Maternal-Fetal Medicine; Caughey, A.B.; Cahill, A.G.; Guise, J.M.; Rouse, D.J. Safe prevention of the primary cesarean delivery. Am. J. Obstet. Gynecol. 2014, 210, 179-193. [CrossRef] [PubMed]

3. Macfarlane, A.J.; Blondel, B.; Mohangoo, A.D.; Cuttini, M.; Nijhuis, J.; Novak, Z.; Olafsdottir, H.S.; Zeitlin, J.; Euro-Peristat Scientific Committee. Wide differences in mode of delivery within Europe: Risk-stratified analyses of aggregated routine data from the Euro-Peristat study. BJOG 2016, 123, 559-568. [CrossRef] [PubMed]

4. Vieira, G.O.; Fernandes, L.G.; de Oliveira, N.F.; Silva, L.R.; Vieira Tde, O. Factors associated with cesarean delivery in public and private hospitals in a city of northeastern Brazil: A cross-sectional study. BMC Pregnancy Childbirth 2015, 15, 132. [CrossRef] [PubMed]

5. Mueller, N.T.; Mao, G.; Bennet, W.L.; Hourigan, S.K.; Dominguez-Bello, M.G.; Appel, L.J.; Wang, X. Does vaginal delivery mitigate or strengthen the intergenerational association of overweight and obesity? Findings from the Boston Birth Cohort. Int. J Obes. 2017, 41, 497-501. [CrossRef] [PubMed]

6. Mueller, N.T.; Whyatt, R.; Hoepner, L.; Oberfield, S.; Dominguez-Bello, M.G.; Widen, E.M.; Hassoun, A.; Perera, F.; Rundle, A. Prenatal exposure to antibiotics, cesarean section and risk of childhood obesity. Int. J. Obes. 2015, 39, 665-670. [CrossRef] [PubMed]

7. Mueller, N.T.; Bakacs, E.; Combellick, J.; Grigoryan, Z.; Dominguez-Bello, M.G. The infant microbiome development: Mom matters. Trends Mol. Med. 2015, 21, 109-117. [CrossRef] [PubMed]

8. Rusconi, F.; Zugna, D.; Annesi-Maesano, I.; Baiz, N.; Barros, H.; Correia, S.; Duijts, L.; Forastiere, F.; Inskip, H.; Kelleher, C.C.; et al. Mode of Delivery and Asthma at School Age in 9 European Birth Cohorts. Am. J. Epidemiol. 2017, 185, 465-473. [CrossRef] [PubMed]

9. Martinez, K.A.; Devlin, J.C.; Lacher, C.R.; Yin, Y.; Cai, Y.; Wang, J.; Dominguez-Bello, M.G. Increased weight gain by C-section: Functional significance of the primordial microbiome. Sci. Adv. 2017, 3. [CrossRef] [PubMed]

10. Makino, H.; Kushiro, A.; Ishikawa, E.; Muylaert, D.; Kubota, H.; Sakai, T.; Oishi, K.; Martin, R.; Ben Amor, K.; Oozeer, R.; et al. Transmission of intestinal Bifidobacterium longum subsp. longum strains from mother to infant, determined by multilocus sequencing typing and amplified fragment length polymorphism. Appl. Environ. Microbiol. 2011, 77, 6788-6793. [CrossRef] [PubMed]

11. Makino, H.; Kushiro, A.; Ishikawa, E.; Kubota, H.; Gawad, A.; Sakai, T.; Oishi, K.; Martin, R.; Ben-Amor, K.; Knol, J.; et al. Mother-to-infant transmission of intestinal bifidobacterial strains has an impact on the early development of vaginally delivered infant's microbiota. PLoS ONE 2013, 8. [CrossRef] [PubMed]

12. Jost, T.; Lacroix, C.; Braegger, C.P.; Rochat, F.; Chassard, C. Vertical mother-neonate transfer of maternal gut bacteria via breastfeeding. Environ. Microbiol. 2014, 16, 2891-2904. [CrossRef] [PubMed]

13. Funkhouser, L.J.; Bordenstein, S.R. Mom knows best: The universality of maternal microbial transmission. PLoS Biol. 2013, 11. [CrossRef] [PubMed]

14. Azad, M.B.; Konya, T.; Persaud, R.R.; Guttman, D.S.; Chari, R.S.; Field, C.J.; Sears, M.R.; Mandhane, P.J.; Turvey, S.E.; Subbarao, P.; et al. Impact of maternal intrapartum antibiotics, method of birth and breastfeeding on gut microbiota during the first year of life: A prospective cohort study. BJOG 2016, 123, 983-993. [CrossRef] [PubMed]

15. Dominguez-Bello, M.G.; Costello, E.K.; Contreras, M.; Magris, M.; Hidalgo, G.; Fierer, N.; Knight, R. Delivery mode shapes the acquisition and structure of the initial microbiota across multiple body habitats in newborns. Proc. Natl. Acad. Sci. USA 2010, 107, 11971-11975. [CrossRef] [PubMed]

16. Martin, R.; Makino, H.; Cetinyurek Yavuz, A.; Ben-Amor, K.; Roelofs, M.; Ishikawa, E.; Kubota, H.; Swinkels, S.; Sakai, T.; Oishi, K.; et al. Early-Life Events, Including Mode of Delivery and Type of Feeding, Siblings and Gender, Shape the Developing Gut Microbiota. PLoS ONE 2016, 11. [CrossRef] [PubMed]

17. Shin, H.; Pei, Z.; Martinez, K.A.; Rivera-Vinas, J.I.; Mendez, K.; Cavallin, H.; Dominguez-Bello, M.G. The first microbial environment of infants born by C-section: The operating room microbes. Microbiome 2015, 3, 59. [CrossRef] [PubMed]

18. Bokulich, N.A.; Chung, J.; Battaglia, T.; Henderson, N.; Jay, M.; Li, H.; Lieber, A.D.; Wu, F.; Perez-Perez, G.I.; Chen, Y.; et al. Antibiotics, birth mode, and diet shape microbiome maturation during early life. Sci. Transl. Med. 2016, 8. [CrossRef] [PubMed]

19. Aagaard, K.; Ma, J.; Antony, K.M.; Ganu, R.; Petrosino, J.; Versalovic, J. The placenta harbors a unique microbiome. Sci. Transl. Med. 2014, 6. [CrossRef] [PubMed] 
20. Romano-Keeler, J.; Moore, D.J.; Wang, C.; Brucker, R.M.; Fonnesbeck, C.; Slaughter, J.C.; Li, H.; Curran, D.P.; Meng, S.; Correa, H.; et al. Early life establishment of site-specific microbial communities in the gut. Gut Microbes 2014, 5, 192-201. [CrossRef] [PubMed]

21. Walker, R.W.; Clemente, J.C.; Peter, I.; Loos, R.J.F. The prenatal gut microbiome: Are we colonized with bacteria in utero? Pediatr. Obes. 2017, 12 (Suppl. 1), 3-17. [CrossRef] [PubMed]

22. Caporaso, J.G.; Lauber, C.L.; Walters, W.A.; Berg-Lyons, D.; Lozupone, C.A.; Turnbaugh, P.J.; Fierer, N.; Knight, R. Global patterns of $16 \mathrm{~S}$ rRNA diversity at a depth of millions of sequences per sample. Proc. Natl. Acad. Sci. USA. 2011, 108 (Suppl. 1), 4516-4522. [CrossRef] [PubMed]

23. Caporaso, J.G.; Kuczynski, J.; Stombaugh, J.; Bittinger, K.; Bushman, F.D.; Costello, E.K.; Fierer, N.; Pena, A.G.; Goodrich, J.K.; Gordon, J.I.; et al. QIIME allows analysis of high-throughput community sequencing data. Nat. Methods 2010, 7, 335-336. [CrossRef] [PubMed]

24. DeSantis, T.Z.; Hugenholtz, P.; Larsen, N.; Rojas, M.; Brodie, E.L.; Keller, K.; Huber, T.; Dalevi, D.; Hu, P.; Andersen, G.L. Greengenes, a chimera-checked $16 \mathrm{~S}$ rRNA gene database and workbench compatible with ARB. Appl. Environ. Microbiol. 2006, 72, 5069-5072. [CrossRef] [PubMed]

25. Edgar, R.C. Search and clustering orders of magnitude faster than BLAST. Bioinformatics 2010, 26, $2460-2461$. [CrossRef] [PubMed]

26. Caporaso, J.G.; Bittinger, K.; Bushman, F.D.; DeSantis, T.Z.; Andersen, G.L.; Knight, R. PyNAST: A flexible tool for aligning sequences to a template alignment. Bioinformatics 2010, 26, 266-267. [CrossRef] [PubMed]

27. Lozupone, C.; Hamady, M.; Knight, R. UniFrac-An online tool for comparing microbial community diversity in a phylogenetic context. BMC Bioinformatics 2006, 7, 371. [CrossRef] [PubMed]

28. Kelly, B.J.; Gross, R.; Bittinger, K.; Sherrill-Mix, S.; Lewis, J.D.; Collman, R.G.; Bushman, F.D.; Li, H. Power and sample-size estimation for microbiome studies using pairwise distances and PERMANOVA. Bioinformatics 2015, 31, 2461-2468. [CrossRef] [PubMed]

29. Segata, N.; Izard, J.; Waldron, L.; Gevers, D.; Miropolsky, L.; Garrett, W.S.; Huttenhower, C. Metagenomic biomarker discovery and explanation. Gen. Biol. 2011, 12. [CrossRef] [PubMed]

30. Langille, M.G.; Zaneveld, J.; Caporaso, J.G.; McDonald, D.; Knights, D.; Reyes, J.A.; Clemente, J.C.; Burkepile, D.E.; Vega Thurber, R.L.; Knight, R.; et al. Predictive functional profiling of microbial communities using 16S rRNA marker gene sequences. Nat. Biotechnol. 2013, 31, 814-821. [CrossRef] [PubMed]

31. Kanehisa, M.; Goto, S.; Sato, Y.; Kawashima, M.; Furumichi, M.; Tanabe, M. Data, information, knowledge and principle: Back to metabolism in KEGG. Nucleic Acids Res. 2014, 42. [CrossRef] [PubMed]

32. Pantoja-Feliciano, I.G.; Clemente, J.C.; Costello, E.K.; Perez, M.E.; Blaser, M.J.; Knight, R.; Dominguez-Bello, M.G. Biphasic assembly of the murine intestinal microbiota during early development. ISME J. 2013, 7, 1112-1115. [CrossRef] [PubMed]

33. Dominguez-Bello, M.G.; De Jesus-Laboy, K.M.; Shen, N.; Cox, L.M.; Amir, A.; Gonzalez, A.; Bokulich, N.A.; Song, S.J.; Hoashi, M.; Rivera-Vinas, J.I.; et al. Partial restoration of the microbiota of cesarean-born infants via vaginal microbial transfer. Nat. Med. 2016, 22, 250-253. [CrossRef] [PubMed]

34. Kunji, E.R.; Mierau, I.; Hagting, A.; Poolman, B.; Konings, W.N. The proteolytic systems of lactic acid bacteria. Antonie Van Leeuwenhoek 1996, 70, 187-221. [CrossRef] [PubMed]

35. Jiang, T.; Savaiano, D.A. In vitro lactose fermentation by human colonic bacteria is modified by Lactobacillus acidophilus supplementation. J. Nutr. 1997, 127, 1489-1495. [PubMed]

36. Angelakis, E.; Armougom, F.; Million, M.; Raoult, D. The relationship between gut microbiota and weight gain in humans. Future Microbiol. 2012, 7, 91-109. [CrossRef] [PubMed]

37. Soergel, K.H. Colonic fermentation: Metabolic and clinical implications. Clin. Investig. 1994, 72, $742-748$. [CrossRef] [PubMed]

38. Nagpal, R.; Tsuji, H.; Takahashi, T.; Kawashima, K.; Nagata, S.; Nomoto, K.; Yamashiro, Y. Sensitive Quantitative Analysis of the Meconium Bacterial Microbiota in Healthy Term Infants Born Vaginally or by Cesarean Section. Front. Microbiol. 2016, 7, 1997. [CrossRef] [PubMed]

39. Chu, D.M.; Ma, J.; Prince, A.L.; Antony, K.M.; Seferovic, M.D.; Aagaard, K.M. Maturation of the infant microbiome community structure and function across multiple body sites and in relation to mode of delivery. Nat. Med. 2017, 23, 314-326. [CrossRef] [PubMed]

40. Mueller, N.T.; Shin, H.; Pizoni, A.; Werlang, I.C.; Matte, U.; Goldani, M.Z.; Goldani, H.A.; Dominguez-Bello, M.G. Birth mode-dependent association between pre-pregnancy maternal weight status and the neonatal intestinal microbiome. Sci. Rep. 2016, 6, 23133. [CrossRef] [PubMed] 
41. Perez-Munoz, M.E.; Arrieta, M.C.; Ramer-Tait, A.E.; Walter, J. A critical assessment of the "sterile womb" and "in utero colonization" hypotheses: Implications for research on the pioneer infant microbiome. Microbiome 2017, 5, 48. [CrossRef] [PubMed]

42. Heineck, I.; Ferreira, M.B.; Schenkel, E.P. Prescribing practice for antibiotic prophylaxis for cesarean section in a teaching hospital in Brazil. Am. J. Infect. Control. 2002, 30, 341-345. [CrossRef] [PubMed]

43. Farret, T.C.; Dalle, J.; Monteiro Vda, S.; Riche, C.V.; Antonello, V.S. Risk factors for surgical site infection following cesarean section in a Brazilian Women's Hospital: A case-control study. Braz. J. Infect. Dis. 2015, 19, 113-117. [CrossRef] [PubMed]

44. Nguyen, D.P.; Gerber, S.; Hohlfeld, P.; Sandrine, G.; Witkin, S.S. Mycoplasma hominis in mid-trimester amniotic fluid: Relation to pregnancy outcome. J. Perinat. Med. 2004, 32, 323-326. [CrossRef] [PubMed]

45. Cassell, G.H.; Davis, R.O.; Waites, K.B.; Brown, M.B.; Marriott, P.A.; Stagno, S.; Davis, J.K. Isolation of Mycoplasma hominis and Ureaplasma urealyticum from amniotic fluid at 16-20 weeks of gestation: Potential effect on outcome of pregnancy. Sex. Transm. Dis. 1983, 10, 294-302. [PubMed]

46. Bearfield, C.; Davenport, E.S.; Sivapathasundaram, V.; Allaker, R.P. Possible association between amniotic fluid micro-organism infection and microflora in the mouth. BJOG 2002, 109, 527-533. [CrossRef] [PubMed]

47. Jimenez, E.; Fernandez, L.; Marin, M.L.; Martin, R.; Odriozola, J.M.; Nueno-Palop, C.; Narbad, A.; Olivares, M.; Xaus, J.; Rodriguez, J.M. Isolation of commensal bacteria from umbilical cord blood of healthy neonates born by cesarean section. Curr. Microbiol. 2005, 51, 270-274. [CrossRef] [PubMed]

48. Steel, J.H.; Malatos, S.; Kennea, N.; Edwards, A.D.; Miles, L.; Duggan, P.; Reynolds, P.R.; Feldman, R.G.; Sullivan, M.H. Bacteria and inflammatory cells in fetal membranes do not always cause preterm labor. Pediatr. Res. 2005, 57, 404-411. [CrossRef] [PubMed]

49. Gomez de Aguero, M.; Ganal-Vonarburg, S.C.; Fuhrer, T.; Rupp, S.; Uchimura, Y.; Li, H.; Steinert, A.; Heikenwalder, M.; Hapfelmeier, S.; Sauer, U.; et al. The maternal microbiota drives early postnatal innate immune development. Science 2016, 351, 1296-1302. [CrossRef] [PubMed]

50. Koleva, P.T.; Kim, J.S.; Scott, J.A.; Kozyrskyj, A.L. Microbial programming of health and disease starts during fetal life. Birth Defects Res. C Embryo Today 2015, 105, 265-277. [CrossRef] [PubMed]

51. Hansen, R.; Scott, K.P.; Khan, S.; Martin, J.C.; Berry, S.H.; Stevenson, M.; Okpapi, A.; Munro, M.J.; Hold, G.L. First-Pass Meconium Samples from Healthy Term Vaginally-Delivered Neonates: An Analysis of the Microbiota. PLoS ONE 2015, 10. [CrossRef] [PubMed]

52. Sunderarajan, K.; Kelkar, S.S. Bacterial flora of meconium and faeces during the first year of life. Indian J. Pediatr. 1979, 46, 92-95. [CrossRef] [PubMed] 